\title{
Women Empowerment: Challenges for the Global Tourism
}

\author{
PhD candidate Katina Popova \\ University of Economics - Varna, Varna, Bulgaria \\ katina_popova@ue-varna.bg
}

\begin{abstract}
Nowadays, an important topic on a global scale is the gender equality and the female empowerment. In some countries, there are women who still suffer some forms of direct or indirect discrimination. Overcoming these problems was set back in 2000 in the United Nations Millennium Development Goals. Now the global citizenship is seeking for alternative ways to improve the socio-economic state of the womanhood. A tool for minimizing the negative aspects of young women's life can be considered the international tourism. It empowers the social group in two ways: psychologically and economically. The aim of the current study is to discuss the multifunctional role of tourism in the process of female gender identity protection. Furthermore, the research sets up some challenges for the global tourism facing the new role of women on the world stage.
\end{abstract}

Keywords: women empowerment; tourism; solo traveling; challenges

JEL Code: Z320; doi:10.36997/IJUSV-ESS/2019.8.1.3

\section{Introduction}

The trials of Modernity have gradually succeeded in blurring the concepts of male and female roles in the live of global society. Emancipation and the struggle for enjoying equal rights have become typical features of the modern woman's personality. However, it is debatable whether the establishment of pure equality benefits both sexes. The topic has been widely discussed in the scientific literature, fiction and informal writings in the Internet and Social media. Women's new social role allows them to win more rights for themselves, including participation in management and ability to travel freely and solo. The relatively easy access to almost all parts of the world has its negative effects. The main one is the possibility of gender, ethnic or religious violence.

Researches in the field of tourism formulate two main paradoxes: "tourism as an industry" and "tourism as a problem" (Cheia, 2010). As an industry and an important sector of the global economy it exerts a significant influence on humanity. As a problem it refers not only to the rapid growth and peak levels reached, but also to the challenges of the alternative choices, the autonomy of the travel decision and the increase in the number of women both employees and consumers in tourism. The subject of research in this paper is the changed social role of women. Its object is the impact of tourism on the development of a young female personality. The report aimed to formulate some challenges and alternatives to the global tourism sector in relation to the protection of women's individuality. For its realization the following research tasks were set up: description of the female society social transformation; analysis of global trends in tourism industry; specifying the qualitative and quantitative parameters of young women employment in tourism and female solo traveling.

\section{Challenges for contemporary women}

The stereotypical perception of female "reproductive" and male "leading" roles today is considered old-fashioned. However, there is still some gender inequality worldwide. Women are defined as "unpaid workforce" (being employed in the "field of unpaid job") and men are still considered main generators of family income (Stoyanova et al., 2008). The modern woman is affected by a number of factors and circumstances that impede her final equalization to the male population. Girls and young women are among the most vulnerable social groups around the world. The threats can be systemized as following:

$\checkmark$ Climate change - the impacts of climate change are sensibly felt by poor and isolated people, mostly women. They lose their lives in natural disasters 14 times more often than men. The 
International Bank for Reconstruction and Development reports that $80 \%$ of the victims of Asian tsunami in 2004 were women (Mearns et al., 2010). Similarly, in 2007, about 1.5 million people in 18 African countries were left homeless because of rains and floods, and women and children represented more than three quarters of them (Hart et al., 2014). Survey of London College of Economics in the United Kingdom showed that in 141 examined countries in a case of disaster the rescue was more likely to help boys (Swarup et al., 2011). The female vulnerability to disasters and cataclysms is due also to factors such as cultural and religious restrictions on women's mobility which support unequal access to tangible and intangible goods, and thus delay the development of the female personality;

$\checkmark$ HIV/AIDS infections - in 2009 World Health Organization (WHO) claimed that the main cause of death for women of reproductive age and young girls is HIV/AIDS. In most cases, the causes of the infection are due to the low level of sexual education of young women, early debut in sex, unprotected sex and frequent partner changes ${ }^{1}$. This defines them as the most endangered group in the global population;

$\checkmark$ Early marriage - despite the obvious global trend of marriage postponement, in some parts of the world, early marriage is leading to an increase in the number of women who gave birth in their early twenties or even before turning legal age. Marrying and childbearing usually deprives young women of the opportunity to seek better chances for skill enhancement, schooling and employment ${ }^{2}$;

$\checkmark$ Violence - in all its forms (physical, emotional, sexual, forced marriage and trafficking) violence against women has social and economic consequences on individuals, families and communities. According to WHO in the last few years have been abused $29 \%$ of young women aged 15-19 years and more than 30\% whose age is in between the ranges of 20-24 years and 25-29 years. On a global scale no more than $30 \%$ of the victims seek institutional support (Chandra-Mouli et al., 2013);

$\checkmark$ Workplace discrimination - many studies are proving that on the labor market the gender gap is already closed. Despite the increasing female participation in the corporate management or even in governance, men remain more advantaged on the work place. In the European Union (EU) fewer than 1 in 10 companies has a female chair or Chief Executive Officer (CEO) ${ }^{3}$. Discrimination is detected not only in respect of the prestige of the profession, but also in the distribution of time. Mothers struggle to find the balance between the expectations of high status career and the responsibilities at home (Plickert et al., 2017). Scientists consider that when referring to the salary, the pay gap between men and women will be eliminated by 2045 (Kitchen et al., 2018).

Gender equality is not only a fundamental human right, but also a necessary prerequisite for a peaceful and sustainable world. The attempts to minimize the discrimination should be linked to the elimination of all forms of violence against women and young girls, including trafficking and sexual exploitation and the usage of information and communication technologies (ICT) for promoting women's rights.

\section{Characteristics of women's new social role}

The role of the woman in social life was a great concern for the ancient Greek philosophers. For Plato, the human soul has no gender. Women are considered equal to men, as the differences between them are purely physical (Allen, 1987). On the other side, Aristotle states that women are not only weaker physically, but also mentally and emotionally. According to him, Nature contains the potential for completion of things. Therefore, the subordinate role of women is determined by their natural immanent qualities (Allen, 1987; Zdravkova, 2009).

Many years later, the society has not reached a consensus on the women's role in the life of

\footnotetext{
${ }^{1}$ According to International Center for Research on Women (ICRW)

${ }^{2}$ According to World Economic Forum (WEF)

${ }^{3}$ According to European Union (EU)
} 
the nations. Globalization managed to "transfer" some male qualities and responsibilities to women and that became crucial for the change in the female social role. Fertility levels have declined below the sufficient on a global scale, the marriages are being postponed and the relationships became more fragile (Oláh et al., 2018). All this is due to the decision of the modern young woman to seek more opportunities for herself - from the chance to get a well-paid job, to the improvement of her knowledge, skills and competences. Women's empowerment can be defined as a process of transformation trough which women became the protagonists of historical, cultural, political and social life (Poveda, 2015). While in the past women had no rights to vote and take part in elections, nowadays this tradition has dropped in the biggest part of the world. In EU, for example, the current number of female senior ministers is the highest since 2004 - about $30.5 \%$. Education is a mandatory requirement for leadership positions. On European level women's share in the group of university graduates is $60 \%{ }^{5}$. The spectacular enhancement of female academic and technicaladministrative skills plays an essential role in improving women's confidence when reaching the labor market (Escuerdo, 2010). The factors that enabled women's economic empowerment can be summarized in two main groups: 1) direct factors (education, skills development and training; access to quality, decent paid work; address unpaid care and work burdens; access to property, assets and financial services; collective action and leadership; social protection); 2) underlying factors (labor market characteristics; fiscal policy; legal, regulatory and policy framework; gender norms and discriminatory social norms). Those factors are highly interconnected and together form the so called "enabling environment" where women's new role to be improved (Hunt et al., 2016).

The political and economic participation of women ensures their status as citizens enjoying full rights to be active members of the society. In a social aspect, the changes in female behavior are linked to the increased presence of women on the Internet and social media networking sites. According to The Global Gender Gap Report, 22\% of Artificial Intelligence (AI) professionals are female $^{6}$. A challenge for contemporary woman is managing to keep the femininity in a social and psychological aspect. Changing gender roles can be pernicious for the modern society, especially in the Post-Socialist transition countries, where democracy is misunderstood and the adaptation to the new regime is a slow process. The new women's role is most evident in the international tourism.

\section{Contemporary woman and international tourism}

The United Nations Sustainable Development Goal 3 states the following: "promote gender equality and empower women". Achieving this goal requires the involvement of all economic industries, non-governmental sector and other interested parties in eliminating the discrimination against women. International tourism is a fast-growing phenomenon contributing not only in meeting primary and secondary tourist needs but also playing a role of economic resource that reduces unemployment and generates significant incomes. Tourism empowers women as:

- Job generator - according to a study by United Nations World Tourism Organization (UNWTO), irrespectively of the region, the majority of the employees in the sector are women (Bhatnagar, 2018). The percentage varies greatly between the countries and regions - from $2 \%$ to more than $80 \%$ (Chandra, 2004). Statistics show that women represent up to $70 \%$ of the labor force in the hospitality. Especially for Bulgaria, the percentage of female tourism managers is more than 70\%. Globally, tourism has more than twice as many female workers as other industries. Researches show that women are most successful in tourism business and less in other areas (Fruman et al., 2017). In the Global Report on women in tourism UN Women ${ }^{7}$ finds that one in five national tourism governments are led by a woman. In terms of the salary, women are paid about $15 \%$ less than men;

\footnotetext{
${ }^{4}$ According to European Union (EU)

${ }^{5}$ According to European Parliament (EP)

${ }^{6}$ According to World Economic Forum (WEF)

${ }^{7}$ United Nations Entity for Gender Equality and the Empowerment of Women
} 
- Mechanism for rising women's self-esteem - in the light of contemporary woman, tourist activities are a means of emancipation and autonomy of choice. In the last few years, there has been a significant increase in the number of female tourists traveling independently to typical or little known destinations. In the scientific literature this phenomenon is described as "solo tourism". More than $50 \%$ of the solo tourist product consumers are women, mostly representatives of the Millennials and Baby Boomers generations (solotravelworld.com). Solo women travelers have different characteristics and purposes of travel (see Table 1).

Table 1. Women solo travel purposes

\begin{tabular}{|c|l|}
\hline \multicolumn{2}{|c|}{ Travel purposes } \\
\hline Autonomy & $\begin{array}{l}\text { Freedom in choosing the destination and the opportunity to spend their spare } \\
\text { time according to their special interests and desires. }\end{array}$ \\
\hline Escape from everyday life & $\begin{array}{l}\text { Rest from work and family responsibilities; possibility of moving away from } \\
\text { routine and stress. }\end{array}$ \\
\hline New experience & Looking for adventures, physical activities and social contacts. \\
\hline Self-esteem and confidence & Seeking education, skill enhancement and self-understanding. \\
\hline Leisure & $\begin{array}{l}\text { Relaxing, shopping, visiting friends and relatives; feeling comfortable on } \\
\text { being on their own. }\end{array}$ \\
\hline
\end{tabular}

Source: Pereira et al., 2018

Tourism happens to have big impact on women around the world. Indirectly, it eliminates some of the preconditions that burdened women's personality development. The transformation of the cities has influenced women's social dynamics, provoking high levels of mobility and demanding active social presence (Expósito, 2013). Tourism and modern women are inextricably linked. Today, the sector predetermines the change of female personality and that changes set some new trends in the global travel demand (see Fig. 1).

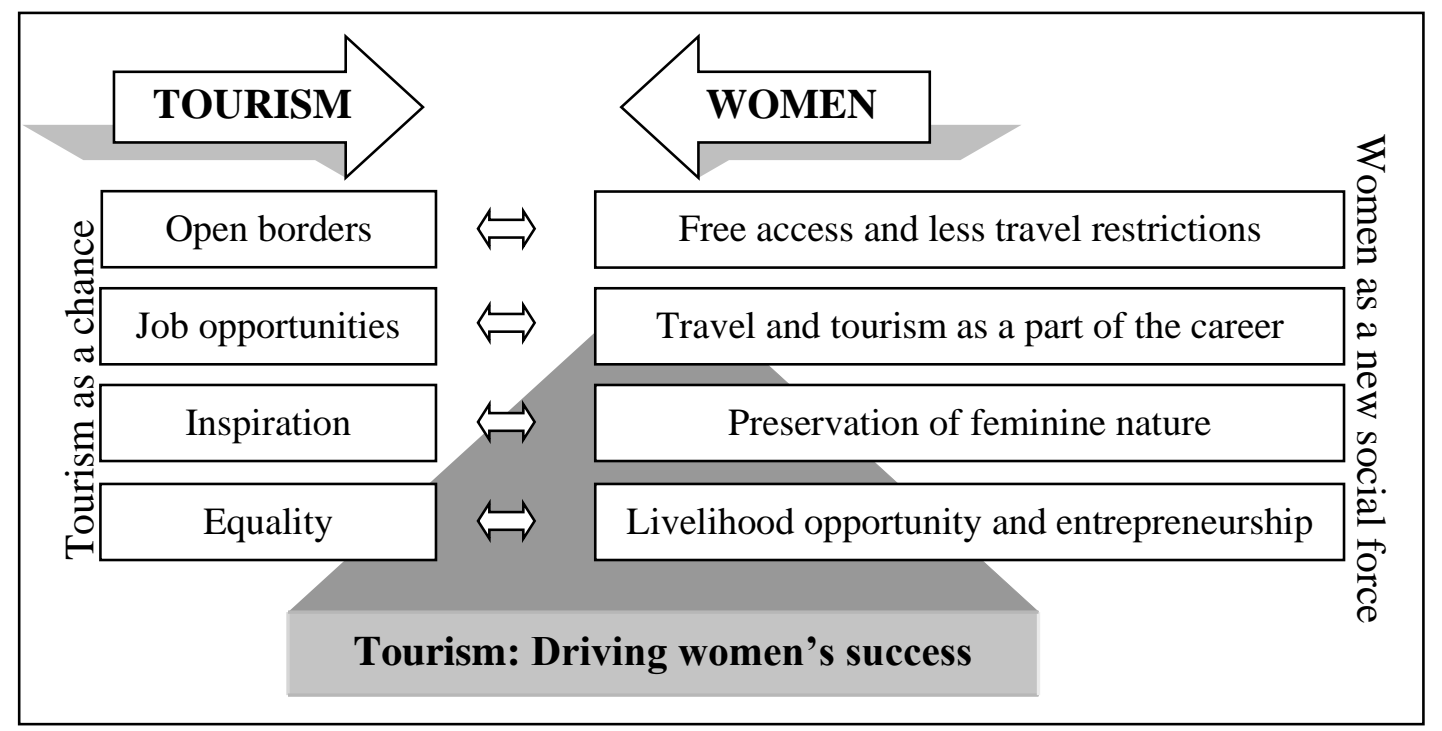

Source: created by the author

Fig. 1. Relationships between tourism and women's new social role

The impact of tourism industry on young women extends beyond the joy of just discovering the destination. International tourism is a tool for expand their social circle, get away from the reality, enjoy themselves, get to know new cultures and habits or even learn a new language.

Despite the changing role of women in the society, the reproduction and family service remain a main form of women's social expression. A problem today is the refusal of men (and some communities in general) to recognize the other women's achievements. As the psychiatrist Morgan 
Scott Peck states in his book "The Road Less Traveled" men define their wives' function in reference to their own living: "Not too long ago in a couples group I heard one of the members state that the "purpose and function" of his wife was to keep their house neat and him well fed. I was aghast at what seemed to me his painfully blatant male chauvinism." (Peck, 2003, p. 165).

A challenge for some young modern women is the need of starting a family. With the increase of the average age for marriage, various accompanying problems arise. This provokes changes in the travel demand and gives rise to new forms of tourism, such as fertility tourism (reproductive tourism).

Some feminist groups understand the international surrogacy as a form of "reproductive trafficking" (Donchin, 2010). This brings to the forefront the need of introduction of term that defines the phenomenon as a medical necessity. The European Society of Human Reproduction and Embryology concluded that most appropriate is the term "cross-border reproductive care" (CBRC) (Paraskou et al., 2017). Fertility tourism is considered as an activity carried out by women (or even couples) with certain reproductive problems which cannot be solved in their own country for some legal or ethic reasons (Matorras, 2005). Another purpose of taking a fertility trip is the woman's attempt to save her marriage, make the family bigger and play the most important role in her life being a mother.

\section{Contemporary women and challenges for the global tourism}

One of the missions of responsible tourism today is to achieve full perfection in equality between men and women. Sector changes happen according to the motto "Women taking the lead". In the current situation the global citizenship is witnessing a dramatically increasing number of women confronting discrimination. The challenges for the global tourism are numerous:

As an industry tourism should continue its development as a tool for increasing female presence in management. A joint study of UNWTO, UN Women, German Cooperation Agency, World Bank Group and Amadeus shows that more and more women are facing the gender stereotypes at work. In 2019 Moroccan women were granted a tour guide license for the first time. In Uganda the Hotel's Owner Association is now led by the first female CEO (www.moderndiplomacy.eu, 2019). In its role as a generator of jobs for women, tourism faces the following challenges (Mohanty et al., 2018):

$>$ Reducing the gender pay gap in the sector;

$>$ Eliminating the orthodox understanding of women's role in society;

$>$ Promoting women's entrepreneurship in tourism;

$>$ Enhancing women's professional realization rates, creating flexible working schedule according to their role as mothers and wives;

$>$ Using upgraded technology and communication methods for information;

$>$ Ensuring women's safety and security on the work place.

Considering women as specific consumers of tourist products and services, the tourist sector should enhance its product portfolio with activities that meet the needs of contemporary female consumer's interests and provide safety and security during their travel and stay.

Small Luxury Hotels of the World states that lately, the growing number of female solo travelers provoked 53\% increase in single occupancy rooms booking. Women's expectations are seriously high for both business and leisure travel. The changes in the sector became from the fact that women understand travel and recreation differently from men (Jeff et al., 2001). A big challenge for the global tourism is the opposition "sensitivity - safety". Some women are especially culturally sensitive (Heckscher, 2012). Trying to understand new cultures and social orders, they often forget the overriding importance of their personal safety and health. The phenomenon is common for all women performing voluntary service, business mission or pro-poor ${ }^{8}$ travelers. A study of American Economic Association shows that women are more likely to face some health

${ }^{8}$ Pro-Poor Tourism: tourism that generates net benefits for the poor (see Roe, 2001). 
issues when traveling. $56 \%$ of female travelers had experiences an illness while abroad. As to the business tourism, $80 \%$ of women declare that they have worried about their personal safety, especially in countries where thefts frequency level is high ${ }^{9}$. Solo traveling women are also at risk of unwanted attention. The possibility of being raped abused or sold as sex slaves still exist in certain countries. The challenges for the global tourism are:

- Reducing the risk of violence and trafficking trough optimization of the legal framework;

- Consolidating world governmental and non-governmental tourism organizations in the field of risk prevention campaigns;

- Using the celebrities' influence for the purposes of special interest tourism advertising campaigns and offers and the promotion of women's rights;

In the beginning of September 2019 Tommy Hilfiger showed off his new fall collection in New York. The show emphasized global messages such as tolerance, integration, equality, as well as empowerment of women.

- Using soft power ${ }^{10}$ tools as a way of overcoming discrimination and gender inequality.

The relationship between tourism and women is likely to increase. Women's leadership in the sector and the increasing number of female independent travel are driving new trends in the global market of tourism services and products. Challenges exist both for women as a social group and for tourism as a phenomenon.

\section{Conclusion}

Woman's role in contemporary society is determined by her right not only to actively work and raise children, but also to take a direct part in the social life as a whole. Contemporary women are an independent and courageous social group with personal income and new understandings of life. Their differentiation from men is due not only to their physical but also to their psychological characteristics such as: sensitivity, delicacy and personal interests. The role of tourism in improving contemporary women's personality can be considered in two ways: demonstrate equality between men and women; defend women's rights which should be valued and respected not only by men, but also by the same gender.

The scenario for the developing countries remains pessimistic. Tourism is far from becoming the engine of women's empowerment in developing regions, as long as gender stereotypes, extreme forms of exploitation and discrimination against them continue to be reproduced, situations that only widen inequalities between men and women. In these regions, the role of tourism will be essential: it can be understood as an important precondition for gender tolerance.

\section{References}

1. Allen, Pr. (1987). Plato, Aristotle, and the concept of woman in early Jewish philosophy. Florilegium, 9 (1), pp. 89-111.

2. Bhatnagar, G. (2018). Responsible tourism and women empowerment in India. [Online] Available from: https://bit.ly/2ZqHtje. [Accessed: 24/08/2019].

3. Chandra-Mouli, V., Amin, A. (2013). Violence against women and girls: forms, levels, consequences, causes \& growing commitment to address it. Geneva: WHO.

4. Chandra, R. (2004). Social development in India. Delhi: Gyan Publishing House, 326 p.

5. Cheia, G. (2010). Research Methods in Tourism. Georeview: Scientific Annals of Stefan cel Mare University of Suceava. Geography Series, 19 (2), pp. 81-94.

6. Donchin, A. (2010). Reproductive tourism and the quest for global gender justice. Bioethics, 24 (7), pp. 323-332.

\footnotetext{
${ }^{9}$ According to American Economic Association (AEA)

${ }^{10}$ Soft power of tourism: the ability to influence the behavior of others in order to achieve desired results (see Krustev, 2015).
} 
7. Escuerdo, J. (2010). El papel de las mujeres en la Sociedad de la Información. Revista Internacional de Filosofía, 3 (1), pp. 145-152.

8. Expósito, C. (2013). ¿Es el turismo una oportunidad para la igualdad? [Online]

Available from: https://bit.ly/2L94IZY [Accessed: 24/08/2019].

9. Fruman, C., Twining-Ward, L. (2017). Empowering Women through Tourism. [Online]

Available from: https://bit.ly/2ZqIOBK [Accessed: 24/08/2019].

10. Hart, R., Fisher, S., Kimiagar, B. (2014). Beyond projects: Involving children in community governance as a fundamental strategy for facing climate change. The Challenges of Climate Change. Florence: UNICEF Office of Research, pp. 92-97.

11. Heckscher, Z. (2012). Safety Issues for Women Traveling Solo: Stay Safe But Don't Stay Home. [Online] Available from: https://bit.ly/2NFixSV [Accessed: 27.08.2019].

12. Hunt, A., Samman, E. (2016). Women's economic empowerment: Navigating enablers and constraints: a research report. London: Overseas Development Institute, 40 p.

13. Jeff, G., McElroy, R. (2011). Women's Travel: Consequences and Opportunities [Online] Available from: https://bit.ly/30GtQ0E [Accessed: 27.08.2019].

14. Kitchen, A., Wardell-Johnson, G. (2018). Ending workforce discrimination against women. Melbourne: KPMG International, 17 p.

15. Krustev, V. Turizmat kato geopoliticheski instrument na mekata sila. Tourism in the age of transformation. Varna: Science and Economics, pp. 825-831.

16. Matorras, R. (2005). ¿Turísmo reproductivo o exilio reproductivo? Revista Iberoamericana de fertilidad, 22 (2), pp.85-86.

17. Mearns, R., Norton, A. (2010). Social Dimensions of Climate Change: Equity and Vulnerability in a Warming World. The International Bank for Reconstruction and Development. Washington DC: The World Bank.

18. Mohanty, P., Swain, S., Besra, S. (2018). Women at work: exploring the issues and challenges of women employees in travel and tourism. Indian Journal of Economics and Development, 6 (1), pp. 1-5.

19. Oláh, L., Kotowska, I., Richter, R. (2018). In: G. Doblhammer and J. Gumà (eds.), A Demographic Perspective on Gender, Family and Health in Europe. [Online] Available from: https://bit.ly/2zkgGdN [Accessed: 24.08.2019].

20. Parascou, A., George, B. (2017). The market for reproductive tourism: an analysis with special reference to Greece. Global Health Research and Policy, 1 (1), pp. 2-16.

21. Peck, M. (2003). The Road Less Traveled. 25th Anniversary Edition: A New Psychology of Love, Traditional Values and Spiritual Growth. New York: Simon \& Schuster, 380 p.

22. Pereira, A., Silva, C. (2018). Motivations and experiences of women solo travellers. International journal of multidisciplinarity in business and science, 4 (5), pp. 134-138.

23. Plickert, G., Sterling, J. (2017). Gender Still Matters: Effects of Workplace Discrimination on Employment Schedules of Young Professionals. Laws, 6 (28), pp. 1-22.

24. Poveda, L. (2015). El turismo y el empoderamiento de las mujeres en los países en desarrollo: Historia y agenda geopolítica, [Online] Available from: https://bit.ly/2MH8L2Y [Accessed 27.08.2019].

25. Roe, D. (2001). Pro-Poor Tourism: Harnessing the World's Largest Industry for the World's Poor. World Summit of Sustainable Development. London: International Institute for Environment and Development, $8 \mathrm{p}$.

26. Stoyanova, K., Kirova, A. (2008). Dzhendar neravnestva v plateniya I neplateniya trud v Bulgaria. Sofia: Prof. Marin Drinov Academic Publishing House, 194 p.

27. Swarup et al. (2011). Weathering the storm: Adolescent girls and climate change. London: Plan $\mathrm{UK}, 40 \mathrm{p}$.

28. Zdravkova, Zl. (2009). Rolyata na gruckata zhena v Antichnostta. Scientific works of University of Ruse, 48 (6.2), pp. 209-213. 